\title{
$\mathfrak{A} \mathfrak{i} \mathfrak{i} \mathfrak{i} \mathfrak{v}$
}

bes 2Tpothecer = Bereinz im núrblidjen Tentfdhland für

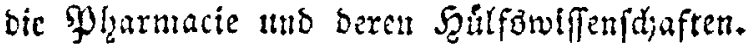

XVII Bandes aweites Sieft.

\section{Errite 2Cotíneilung.}

\section{Bereinzmittheilungen.}

1. Freislifte ser wirtidjen Mitgliebcr bes 2Tpothes Eervereing in norblidjen Teutfidlanb im serfioffenen Sabre 1825 .

Sreife unter ber unmittelbaren Leitung bez Dis reftortumb.

Stri3 Minden.

1. Bilte, greigbireftor und Ifpothefer in Binden.

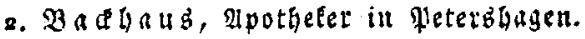

3. Deifferatra, Direltor ber Bibliothet, Medicinalafers

for und Ifothefer in Minten.

4. No ofentbal, Mpotbefer in Siabden.

5. Rutoe, atpothefer in eewern.

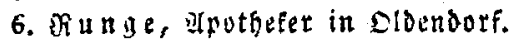

7. Tieman and atbelet in Súbbefe.

8. Befenberg, Ipotbefer in minber.

XVII 28 . 2 Sfft. 


\section{Srits 5erford.}

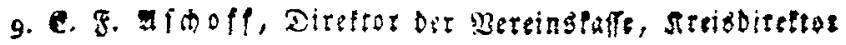
uth apothefer in serford.

10. Irdofi, Mebicinalatientor uno 2lpotseles in Bietefelo.

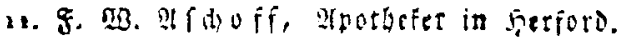

12. Dellus, Tyothefer in viersmold.

13. Oronedoeg, stputbefer in oblterstob.

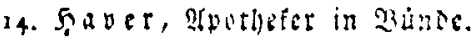

15. Eicliels, Mrpotheter in Enger.

16. Rieffelo, Inotheter in Etriberite.

7. Meuper, Spotbefer in Engit.

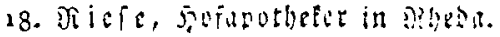

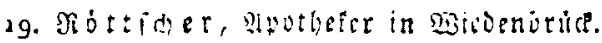

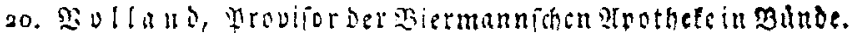

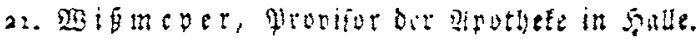

22. Witter, grothefer in aistber.

23. Biegler, Iputbeter in Borgholihauren.

Sreis Pabcrborn.

24. Sobl, steissireftor und stpotheter in Brabel.

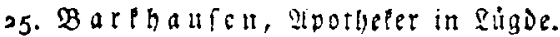

26. Besers, 2husthelet in Deforiat.

27. Dr. Eramer, Irpotgefer in Faderborn.

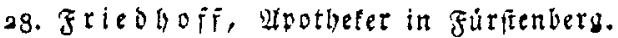

29. (S) dece, Ipotheter in warbutg.

30. Sod, Ifutheler in maderborn.

31. Range, Provitor in Driburg.

32. 2 uiter, Ipotheter in Buter.

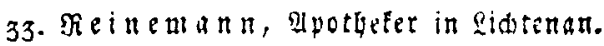

34. Notgeri, Nrovifor in Nittberg.

35. Ed litter, Fpotheter in Eteinbeim.

36. Stratna anu, 2lpotgeter in Enljeotten.

37. Uffelm, Ipotbeter in Sarburg.

38. Dr. Sitting, Eireltor did phatmaloleginden subinets uad atpotgeter in siater. 


\section{Srets 2rnzberg.}

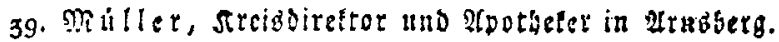

4o. Bilgen, spotbefer in sasplbe.

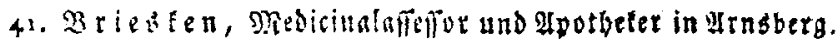

42. (3) $\mathrm{r} a f$, 2lwothefer in Eiegen.

4j. Sa anc, provior in seilaenbad.

4. Sorfoler, Ilpotbefer in Sdmallenberg.

45. Sinb ha

40. Mn a

4. $S$ bith, atpotbetit in Berlabutg.

45. Wrede, Hputhefer in Mefitede.

\section{Rreis Ripptiot.}

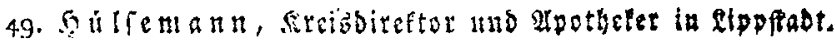
50. SBe ceers, Mnotbefer in Erwitt.

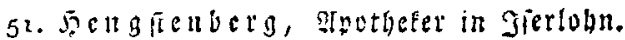

52. 5enfe, Apotbefer in lluma.

53. $\sqrt{3}$ it be, stpotberex in Soefr.

54. Sุug a $\mathfrak{t}$, IpotheẼer in Linen.

55. Seb $\pi, 2$ thothcter in (5efefe.

56. Sithze, Tpotbefer in stibenideib.

57. Rebmann, spotheler in Goeft.

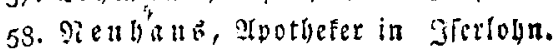

59. Soth ay , Hpotheler in summ.

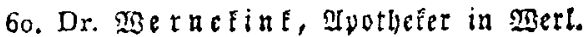

\section{Sreis Rorbbnulen.}

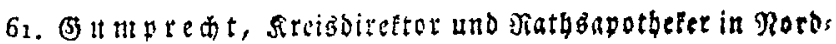
batuen.

62. Eiकols, Thotheler in Elltid.

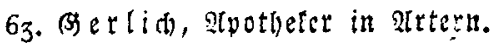

6.. Sinder, Apothefer in Sabia.

65. 5eintid), Apotbefer in allifibt.

66. Seffe, stpothefer in Conderdhanfen.

67. Sicting, Ipothefer in frantergaufer. 
68. Sarit, 2lyothefer in seula.

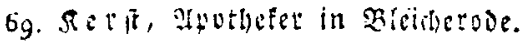

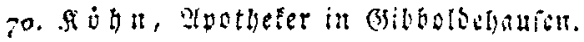

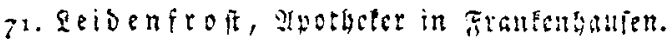

73. Marmutb, Grotbefer in slobleber.

75. Hoppc, Hpotgefer in Mrtern.

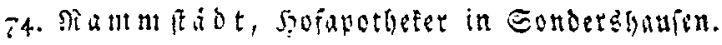

75. Sitter, Spathefer in Sindul.

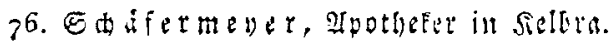

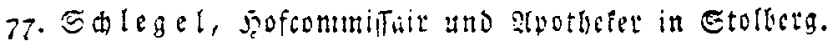

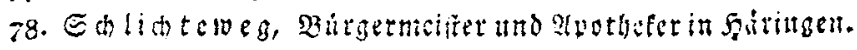

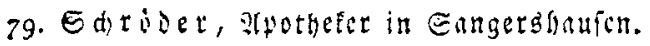

8o. Son al, apothe Eer in Fronfentiaten.

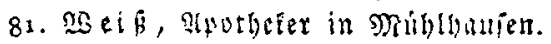

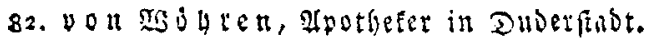

Sireis Grjutt.

83. $\mathfrak{B}$ u

84. I $\mathfrak{a} \mathfrak{n} D$, apothefet in Eómmerda.

35. $\mathfrak{3} i t ;, \mathfrak{B p o t h e l e r}$ in Erfurt.

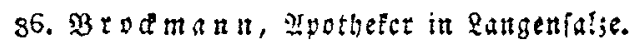

87. Frenjel, Apothelet in Erjurt.

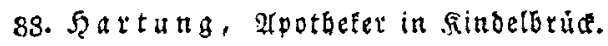

89. Sallenberg, apothefer in SBei

go. Slaucr, Mtyothefer in Mútllaufen.

91. So , Hpothefet in Erfutt.

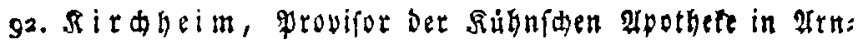
ftadt.

93. Qucas, Stpothefer in Irnftadt.

94. $Q$ Ucab, Spotbetet in Erfurt.

95. Motfotrann, Ipotheter in Shleulingen.

96. Meirig, Inothefer in Langenfalie.

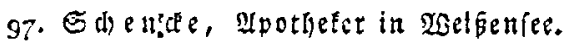

98. Exócl, Trothelet in Jlmenau.

99. Stopel, Ipothefer in Irtufabt. 
100. Dr. Ttomm B D o fff, Şoftath, Profeffor, Ritter Des rothen sisterorbens britter Siaffe, Ipotheter in Etfurt. 101. Bitgand, Apotbeter in Genatidot.

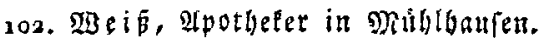

303. $\mathfrak{B}$ ilbelm, Ipotheler in Ereffutt.

Sircis Şannover.

104. Sibli, Steisbireftor und Ipothefer in Soppenbthgge.

105. Etbrot, apotheler in Artzen.

106. Iffia ub, Ifpotheter in Else.

107. \&a arentid $b$, Ipotheler in Sammipring.

108. Sodh, Fpothelet in (s) ronat.

109. $2 \dot{b} \mathfrak{c}$, Ipotheler in Bodenem.

110. Stein, Ipotileler in Bronde.

112. Stieren, Hpotbeter in Salsbetfurt.

112. S dinf, Mpotlefer in Salzhermentorf.

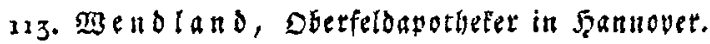

114. TS igsers, Hpothelet in Eldagien.

115. SSitting, Apothetet in Bisperobe.

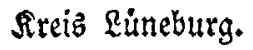

116. Dr. Du $\mathbb{R e n}$ il, sberbergemmifait, Direltor bet bos tanifden Gamalung, Siteiborettor und Hpotheter in SButitorf.

117. Bebre, Ipotheler in Fehbuttg.

12. Bebte, 2potbeter in Stolisenau.

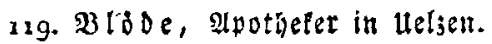

120. 2 uf

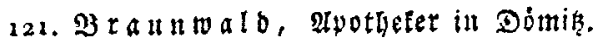

322. Demp wolff, apotheler in Dannenbers.

123. Demploolfi, Sppotheter in Rineburty.

124. gif dier, grpothefer ill f̧agendurg.

125. Frohling, Provitor ber Sfputlyete in Ballum.

126. Mugle, Hpothetcr in fratburg.

127. Yfotendaucr, Mpothefer in thate. 
129. Eaแล

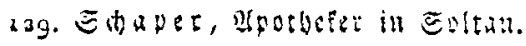

Stris Thitim.

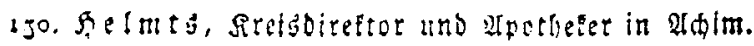

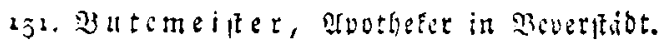

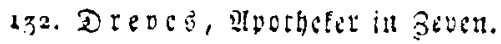

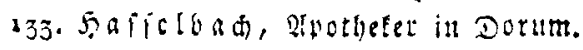

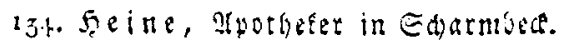

235. Satiens, arpotheter in Stubc.

256. Sio h, stpothetet in Drocitelien.

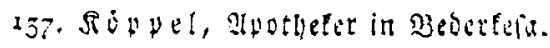

258. Dr. Maller, Itpothefer in Detersbers.

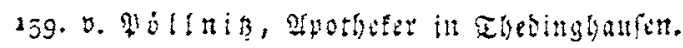

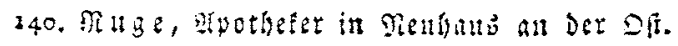

24x. Sattorits, Mpotjefer in Eummitiot.

34. Ners mann, Ifotheler in Etabe.

243. Sist anterg, glpotheter in Dothenburg.

34t. Sgonaeberg, Rqutheter in sagen.

Freis Bioshar.

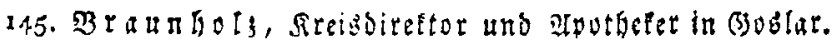

146. Bolft orf, Spotherer in Eimbed.

347. Sotti由all, Ipotheter in Sellerfeld.

148. Sattmann, hem. Fabrit. in (s)oslar.

149. Levit, Srpothefer in andreasberg.

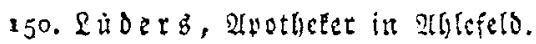

151. Mener, apotheter it Merningetode.

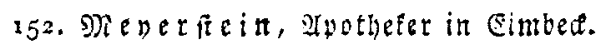

153. Dften, atyotheter in Bostar.

15\%. Editte, dem. Fabrie in Merningetode.

155. Sievers, Ipotbeter in Ealggitter.

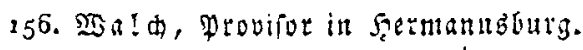

157. 3iera, apotbeter in Eibingerode. 


\section{Stris Dsunbrid.}

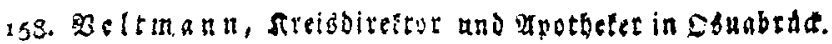

159. Af 5 cend, alpotheter in ecuserid.

160. Itbers, Mporgefer in Sipenbuaten.

16. Panning, פpotheler in lengetid.

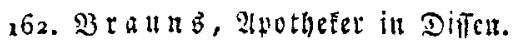

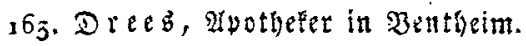

26.. Jitnhaber, spotbeter in Torthorn.

165. Ge $m p t$, Spothefer in Burgiteinfurt.

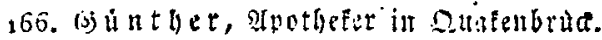

167. Rabler, atpotheter in sinterter.

163. Siertbof, apotheier in Miepuen.

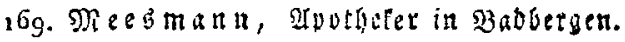

17o. Sieina arotheter in Stgeine.

17i. Rettelhorft, Hyothefer in gourg.

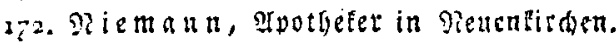

173. S d mibt, Sipotheter in Brumiche.

17\%. Eluiter, Apotheter in Sicfertappefn.

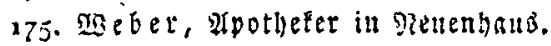

176. $\mathfrak{B}$ e riels, פpotheter in $\mathfrak{B u e r}$.

Sireis Dftirieglano.

17. von Senden, fireisdireftor und afpotbeler in emben.

778. In ton $i$, Ipotheter in Seer.

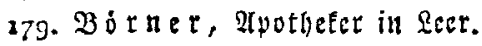

130. Dahm, Provifur der apothete in Bunda.

231. Eber maer, atpothefer in atrif.

182. Einfeld, peovifur ber grpothefe in Bonta.

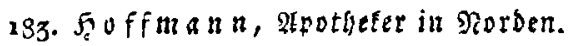

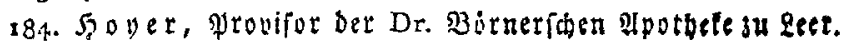

285. Plagge, apothefer in afutid.

186. Nite $\mathfrak{e} \mathfrak{n}$, Apotheter in Mittmund.

187. Niotering, Hyothefer in papenburg.

188. Sander, gpotheler in Morden.

289. S๙⿱ miot, Hpotheter iu Reet. 
19o. Edomern b, מpothefer in Trorben. 193. Egrabe, Mpothefer in petojum. 19a. Springemann, Wrothefer in seer. 299. Eas 194. WG

\section{Drt combinirt: Rippifor Rréts.}

195. Sider, fireisbireltur, Mebicinalafiefior und Ipothes Eer in Búdebutg.

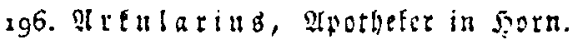

197. Ba oreng, Tpotbeter in siarentols. 299. Dr, $\mathfrak{B}$ randes, frofrath, Dberbireltor Des Bereing utb Itpotbeler in Saljuren.

19g. Greve, ifotheler in polife.

200. Şu (emanti, provifur Der Sipotilete in Datmolb.

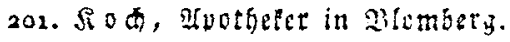

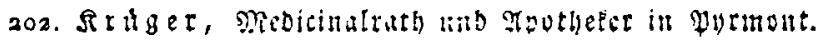

203. D verbea, Fouthefer in Rimbo.

204. Pape, Tpothefer in Sbermitiden.

205. Perdau, Provifur ber Entergeriden Ipothele in Etadthager.

206. Sieinolo, Spotheler in Barnirup. 207. Sduieber, apotbater in Menuodif. 209. $\mathfrak{B a}$ d)

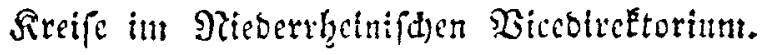

Sreis Ejpan an der Siufr.

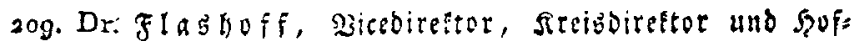
apotbeter in Eilin.

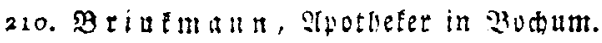

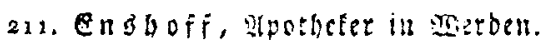

212. Eibifb, Notulueter in seviges.

215. Seiget, ifputhefer in Dorften.

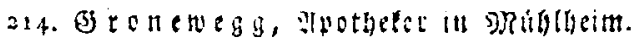


215. Stonne, Spothefer in Mublheim.

216. Sorte, Ifothefer in Eüert.

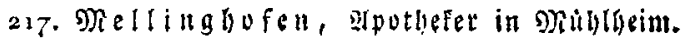

2is. Mi ulter, grpytheter in Selbert.

229. Suertamm, 2lpotheter in Saerden.

azo. Euffe, gpothefer in Buer.

221. Heberfelo, Inothefet in Eifen.

22.2. $\mathfrak{B}$ igeliub, Ipotbefer balelgft.

Sircis Difiploorf.

2zz. Rlein, Steisbitertor und stpotheler in Duffelborf.

234. 3 a 3 , Spotileter Dafelbit.

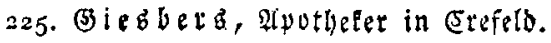

226. S7inge, Ipotheter in Dutigurg.

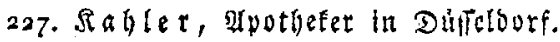

228. Semmerid, Alpotbeer in Sisedeling gofer.

22. Mebe, Ipotheter in Dutfeltorf.

z3o. Dpuermann, Medicitalafefor und Ipotheete in Dul, filborf.

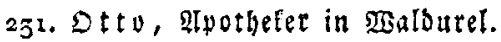

23a. Selb, Stpothefer in $\mathfrak{R e u}$.

233. $\mathfrak{B}$ affen, Hatheier in Borken.

234. Sette, פipothefer il: Linganberg.

355. Boget, sipotbefer in şeirbuerg.

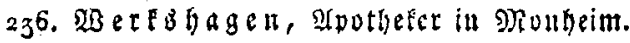

Sreis Elberfelt.

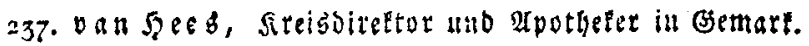

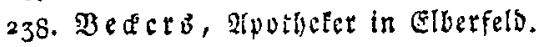

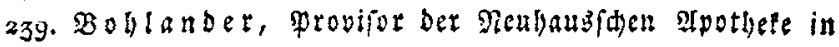
Eolingen.

2fo. Dorr, Prubifur Det Setterfoen Ipothefe in Mettman.

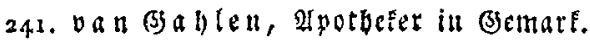

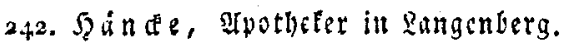

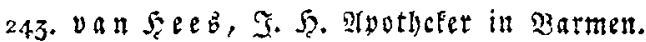

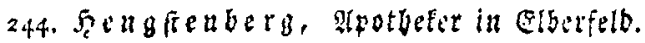


245. Snanp, provior in elbetiels.

2.t6. Sorte, wothetre in Eolimien.

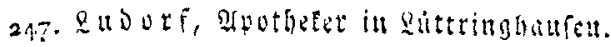

248. Platenins, Inutbefer in Elberfelo.

249. Jic bel, ghotheter in Eranenberg.

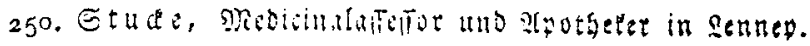

251. Siseber, 2lyothefer in Edroetm.

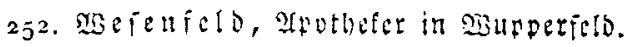

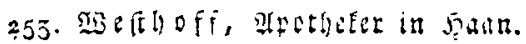

\section{Risis $x_{\text {inten. }}$}

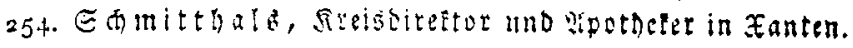

255. Borctarb, Mputfecer in Giat).

zj6. Beraagaub, Hofbefer in sierel.

25\%. Beraifein, Hoothefer ill Emmerid.

253. Clier, Ipothefer in saldetfirben.

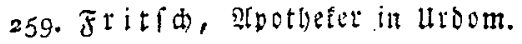

26o. van (j) toer, Sputbefer in Cleve,

261. (5) attutag, Grotbefer itt Bierfer.

262. Fienorids, gipothefer in Cramenburg.

263. Qeu den, fpotheret in Sduchteln.

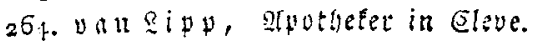

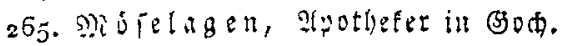

866. peteto, Thortifier in Rees.

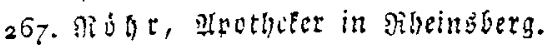

268. Siujis, glyotbefer in Geloern.

269. હ anapp, Npatheter in Saliar.

27o. Spicter, spothefat in smmerio.

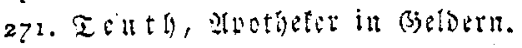

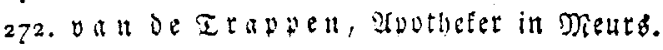

275. 3irloelmi, Noothefer in Xunten.

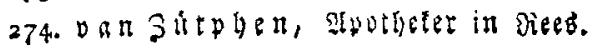


Rreife im Sbertheinifuen Bicesirctorim.

\section{Sircis Eúln.}

275. Sertmener, Wicebireftor bes Dereind, Sreibbireltur unb spothefer in siln. 276. $5 \mathfrak{a} \mathfrak{r}$ fr, glvothefer in Dergheim. 277. Ficáer, glpothefer in Coln.

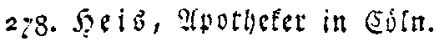

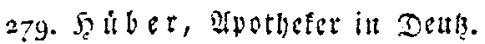

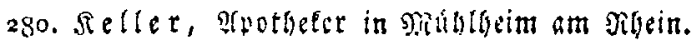
231. Stott, Spothefer in 3eobutg. 2S2. Motitor, Raborant in Sstr. 283. Martini, Ypothefer in 3 raht. 294. Nieffarth, provijor in E⿺tn.

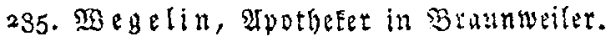

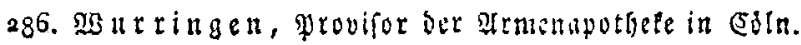

\section{Siris Sonn.}

287. Ba rebe, Sreisbireftur und Itpotheler in Bunn.

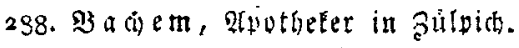
289. $\mathfrak{B} \mathfrak{r}$ is yer, gyothefer in Miumfereifst.

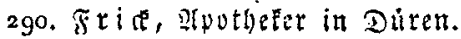

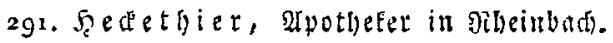

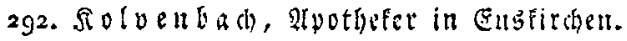

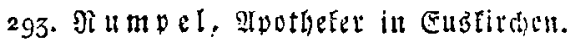

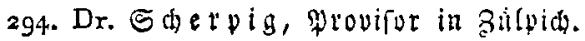
295. Steinda

\section{Sreis Bummerstach.}

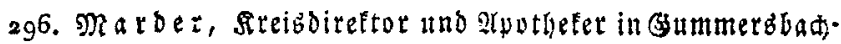

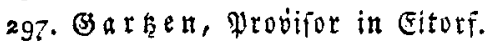
298. F̧ilbett, Ipothefer in Wipuerfirth. 299. $\forall 0 r m$ f 300. In a de 3o1. Shmidt, apothefer in Bensuers. 
303. Eकn is, Npothefet in Matmbredt.

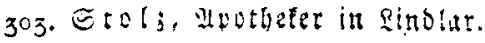

304. Sturm, Trotbefer in Sintobrd.

305. Trifter, stugthefer in Jiunderath.

zo6. Weber, Mrotheter in sintgsinter.

307. Dr, sod ltuer, dem. Fabrif. in Dinuals.

Sreije in Selïifaten Bicebiref́torium.

\section{Areis Eantel.}

308. Ficoler, Mesicinalaterut, Bicebirettor, Areisbiteltor unb Ipotbefer in Saffel.

309. S raun, Npotbefer in Eaffel.

3ro. CLaแb, dyothefer in Sithteran.

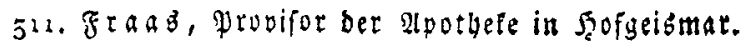

312. Soblet, Ipotheter in Eafel.

313. Sir iger, sipotheler bajeibit.

314. Fenty Petri, Spotheter in Bietenbers.

325. Wfeffer, Wpothefer in (Srebenftein.

316. Nitioe, fofapothefer in Sajel.

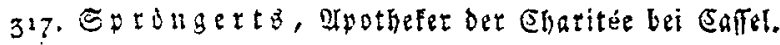

318. Wa a

319. Mild, Mebicinalaffeffor und Apotgeter in Eaffel.

\section{ภreis Treyja.}

320. Dr. $\mathfrak{B}: \mathfrak{g} \mathfrak{a} \delta$, Recisdirstor und Apotheler in Treyfa. $3^{21}$. Ip peli 1 s, Ipotbelet in 5ुomberg.

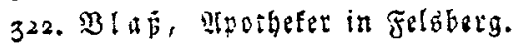

32万. (EI由, Mpothefer in (3)hDenbberg.

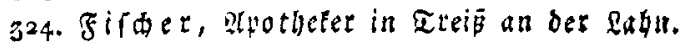

325. Salfeload, Iyptbeter in friklat.

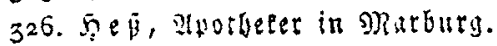

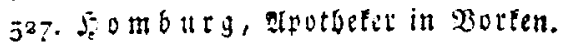

323. firliber, Apotheter in somburg.

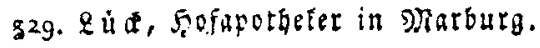


330. Pfeffes, Ipotbefer in sirtsbaik. 331. Shmitt, Itpothefer in Tegberg. 332. $\mathfrak{x a n g e m a n n , ~ a p e t y e t e r ~ i n ~ S a u f d e n b e r g . ~}$

\section{Sreis Shinnfarto.}

333. Şabetland, sreisbireftor and spotbefer in sinnfelo. 334. Bedet, Syothefer in ḩersfatb.

335. Br tider, Bvothefer in Galinngen.

336. S5endnet, Ipotbefer in Echmateutaen.

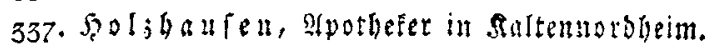

338. Si rael, Provifor in Edimaltalden.

339. Rieblet th, Medicinalateffor uno stpotictet in Sulba.

34.0. Nobdemann, afpotbefer in Dermbich.

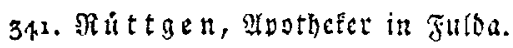

342. Silb net, Ifothefer in Edmalfalben.

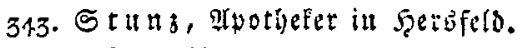

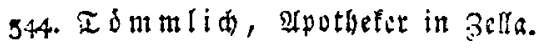

345. Treiber, fefapothefer in Meinumen.

346. Bogt, proviror in Gerbelo.

\section{Areis Manfrieb.}

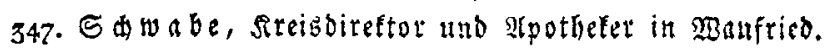

348. $\mathfrak{B} \mathfrak{r a n}$, Itpotgefer in Eidivege.

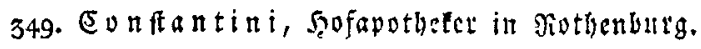

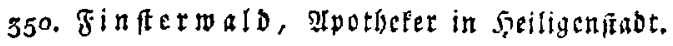

351. Frand $\mathfrak{a} \mathfrak{a}$,

352. If at ttwet, Hpothefer in Eidmege.

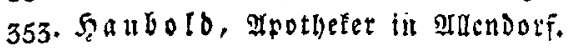

354. Şei

355. $\mathfrak{T}$ offina $n$, apotheter in artendotf.

356. $\mathfrak{S} \mathfrak{i t}$ le, Irothefet in Sontra.

357. Millet, Ipothelet in Mothenkutg.

358. P feffertorn, atpothefer in Matendorf.

359. Soweilett, Inotberet in Dingelfadt. 


\section{Sireis 2rutien.}

36o. Warnagen, Sireisbirettor, Medicinalrath und epc thiter in wrolien.

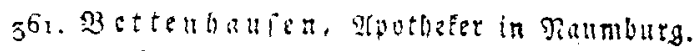

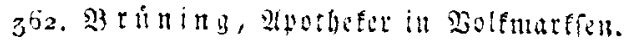

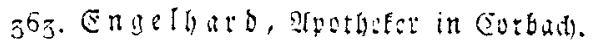

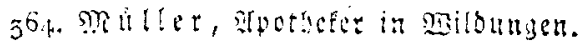

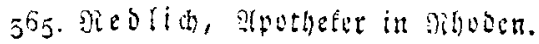

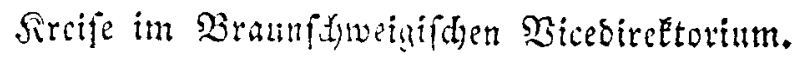

\section{Siris Brauniforeig.}

366. Wasenten, Sreisbireftor mo Itpothefer in Braun (it) weig.

367. I3oming, Shotheter in Soräfelse.

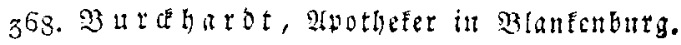

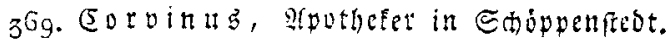

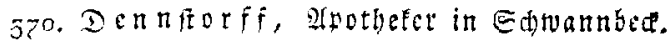

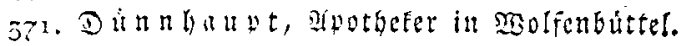

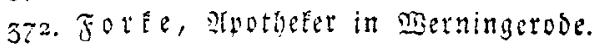

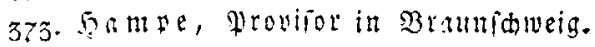

37t. Serjog, slpothefer in Braunfineig.

375. Sablert, Sicebiretor, Siebicinalatefifor und Hpothe:

fer in $\mathfrak{B r}$ rautidineig.

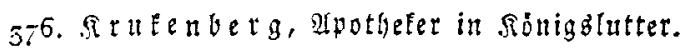

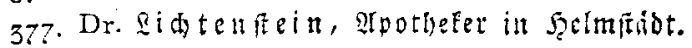

378. Neycr, Spotheler in Meina.

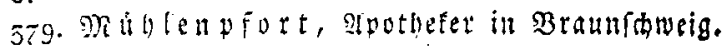

580. Mutler, guctieter in Estiningen.

391. Preiz, Miputlifer in Eeftert.

332. Miefal, Ipothefer in Caluside.

383. Esuf, apotheter in Evebrglie.

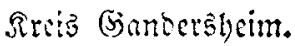

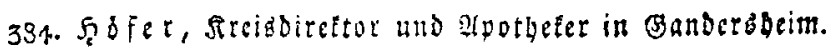




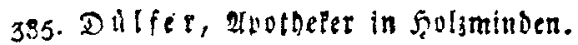
386. Ebrenberg, Nyotheter in Farsburg. 387. Soant, atputhefer in Eeefen.

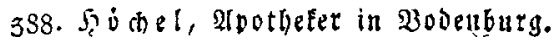
389. Slligel, Stputheter in Daffel. 39o. Q i cuermann, aputhefer in Brinenplan. 391. Sic a ma an, Stpothefer in Sidtenbutg.

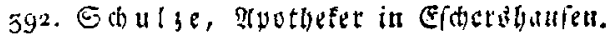
593. Sesmann, Mpotlycter in Bittelde. 394. Etolle, apotheret in Rangelabeim.

\section{Şiccireftoritm Slbenburg.}

\section{Freis Slbenburg.}

395. Dugend, Sircsireftor, Sirtibiteftor und Sofapotheter in Dibenburg.

396. 2 ul 1 c

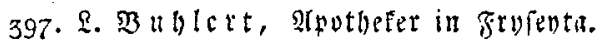

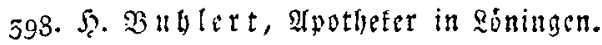

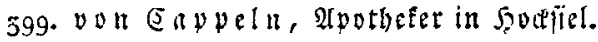

400. Eordemeyer, Hpothefer in Damme.

401. Dettmers, Npothefer in Slbenúrg.

4.2. Fi「d) $x$, spothefer in Dvelgínne.

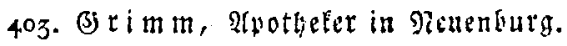

404. $5 \mathfrak{a}^{\mathrm{a}} \boldsymbol{b} \mathrm{man} n$, Iquothefer in Dedersborf.

4.05. Şemmi, âpothefer in Tofins.

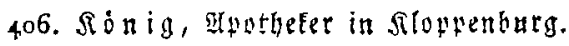

4.07. Frtieger, stputtefer in Nobentitden.

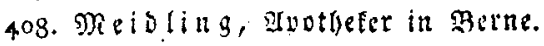

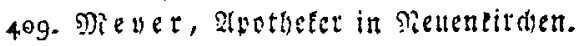

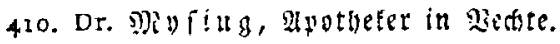

4u. Dloen burg, Sipntheter in Delapenhorf.

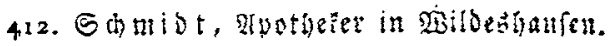

413. Sicgisinand, 2tpothefer in Sewer.

414. Siemers, propitior in elofiteth. 


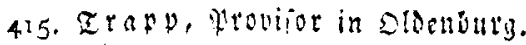
416. Sisolff, Yrovifor in Atend.

Frsije in Sicediretorimu Mectenturg.

Krriz Sioños.

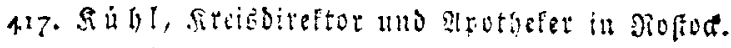

418. Bahlmana, sipothe?et in Gifrow.

419. Berzmana, Spothefar in Sdwann.

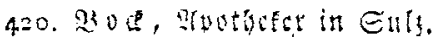

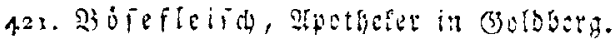

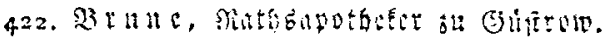

423. Selefle, grovifut in Buthero.

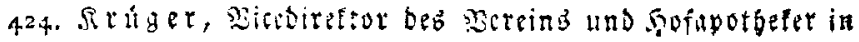
Siofted.

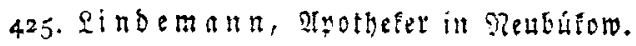

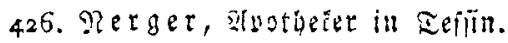

427. It it turitra, spothefer in (s)liftow.

4=8. Edeibel, Ipothelet in Siterow.

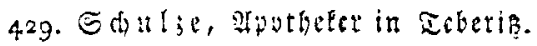

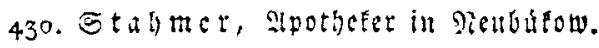

43i. Theoe, provifor in Dobberan.

452. $\Xi$ 由lt $1 \mathrm{ctub}$, Spotheter in plau.

433. Sis ig gers, apetbeker in Subj.

43\%. MHIfow, Slpotbefer in Marloiv.

\section{Mitgis St)werin.}

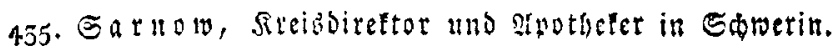
436. Dolberg, Spofaputhefer it Ediverit.

437. Ext

433. (5 $r$ up, Ipothelet in Burin.

439. Is ine dee, Hpothefer in Bjrabow.

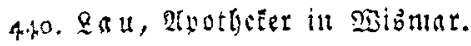

4.r. $\mathfrak{L a m}$ afer, Syothefer in Fagenow.

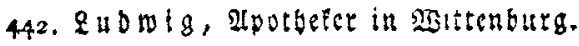


443. Nuttget; Rpothetet in Eterhberg.

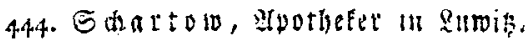

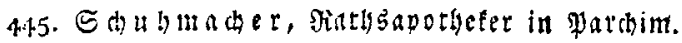

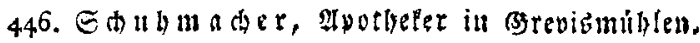
44\%. S (b) 13 , gipotheter in Sichna. 4.ts. Secthorfi, Ifpotheter in sittenburg. 449. $:$ as $\mathrm{mar}$, Ipotgeter in Sdweritt. 450. Solger, surapotherer in subwigstur.

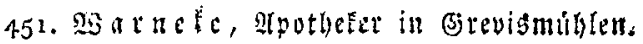
452. Aist tering, glpothefer in Bruer. 453. SGilbelm, stpotgeter in (5noeburds.

\section{Sreis Etavengagen.}

454. B) $\mathrm{t}$ i f 455. Эำ 456. v. $3 \mathfrak{c} \mathfrak{x}$, spothetec in siúbel. 457. $\mathfrak{F} \mathfrak{t} \mathfrak{a} \mathfrak{A}$, afpotheler in stoloes!.

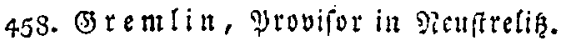
459. Sectmes, Ipotbeter in Pienfulden.

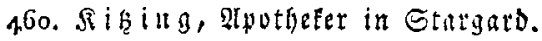
461. Stroc, afothefer in shirow.

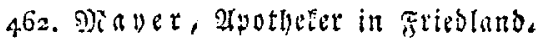

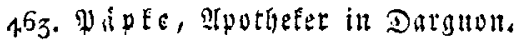
46.. N LitneEe, Stputhafer in Felsfurg.

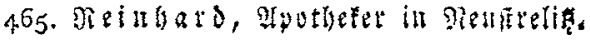

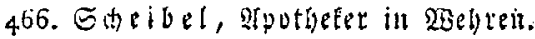
467. S 468. Siente iling, frofapotyeter in senbratbenburg. 469. Spies, arpothefer in פraldow.

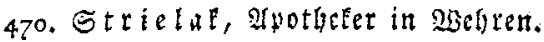

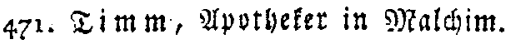

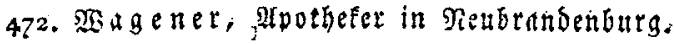

Snoeni nit biefe Qife ber wirlidjen snitglieber bed Sereint in Jalyte $18 z_{5}$ vortegen, erfudten wit bie fúmmtli,

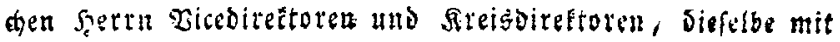
XVII $\mathfrak{B O}, 2.5 \mathrm{ft}$. 
Den Elfen ibrer freife zu vergleiden, uno wenn fith Serin,

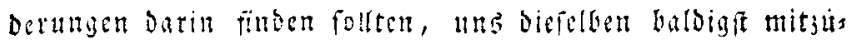
theilen, unb bie jabitinde, bie aus einigen freifen nod) res firen, einjuicnoen, Damit in ber Geueraltechung bes sers eing von 1925 fcine grthlumer entitehell.

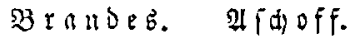

\section{Bur Sicreingtaff.}

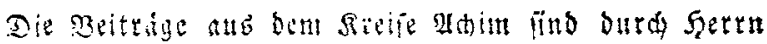

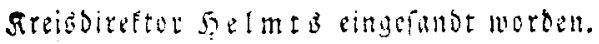

Snlamien ben 20. Tptil 1826 .

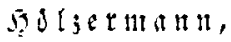

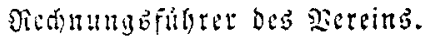

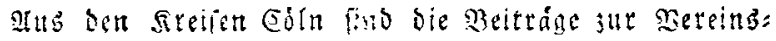
palte simgezangen, besgleiden find foldse fammtlich nub bem

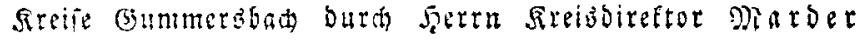
eingefanot notdit.

Eoln im Murs 1826.

Sebltmene:,

Dicrotretor bes Bereing.

\section{3ut Giehนlfen = Llnterfithungalkaffe.}

1) Setra frieorich fortmann aus Jabeturg im

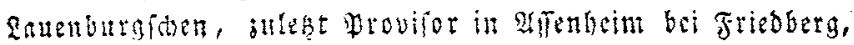

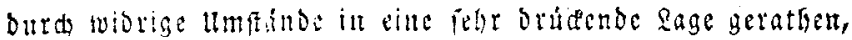

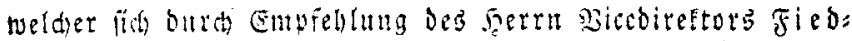
ler in (5affel uno ould leine febr guten Bangnife alb cin

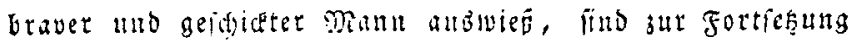

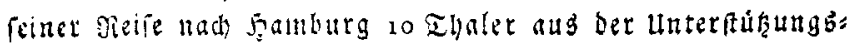
falfe ausgejablt rotben. 